\title{
Changes to the macronutrient profile of food served in care homes for older people after the implementation of the Food Standards Agency guidelines
}

\author{
V. Spraggon ${ }^{1,4}$, S. Kelly ${ }^{1,4}$, R. Masters ${ }^{5}$, M. Lees ${ }^{5}$, A. Adamson ${ }^{2,4}$, C. Seal ${ }^{3,4}$, N. Steen ${ }^{2}$ \\ and P. Moynihan ${ }^{1,4}$ \\ ${ }^{1}$ Institute for Ageing and Health, ${ }^{2}$ Institute of Health and Society, ${ }^{3}$ School of Agriculture, Food and Rural Development, \\ ${ }^{4}$ Human Nutrition Research Centre, Newcastle University, Newcastle upon Tyne NE2 4BW, UK and ${ }^{5}$ Nutrition and Dietetic \\ Service, County Durham and Darlington Community Health Services, Escomb Road, Bishop Auckland DL14 6AB, UK
}

The Food Standards Agency (FSA) developed nutritional guidelines ${ }^{(1)}$ for care homes for older people. As part of a wider study investigating barriers and facilitators to implementing the FSA guidelines and the impact on food and nutrition provided in care homes, the aim of this analysis is to present data on macronutrient profiles of menus before and following guideline implementation.

Detailed information on care home menus before and after the implementation of the guidelines was collected from four residential care homes by direct observation of preparation. A research dietitian intervened in the homes by working with the catering staff to create an amended menu using the FSA guidelines. The mean amounts of macronutrients provided daily by an average 7-d menu were derived using food composition tables ${ }^{(2)}$ and a purpose-written database. The National Research Ethics Service granted favourable opinion.

Three homes made numerous modifications to the dishes served and cooking methods, one home did not make many changes. The main improvement was in mean total fat, where three homes met the FSA target. Although there were large reductions in the mean amounts of saturated fat served, only one home met the FSA target. Targets were not met in any of the homes for total carbohydrate, and only one home met the FSA target for non-milk extrinsic sugars after the intervention. Amounts of protein served remained adequate (see table, values that meet FSA guidelines in bold).

\begin{tabular}{|c|c|c|c|c|c|c|c|c|c|c|}
\hline & & Home 1 & SE & Home 2 & $\mathrm{SE}$ & Home 3 & $\mathrm{SE}$ & Home 4 & $\mathrm{SE}$ & Guidelines \\
\hline \multirow[t]{2}{*}{ Total Energy (KJ/d) } & Before & 7543 & 413 & 7433 & 203 & 8633 & 632 & 6308 & 322 & 8211 \\
\hline & After & 8225 & 179 & 8302 & 572 & 7099 & 190 & 6644 & 346 & \\
\hline \multirow[t]{2}{*}{ Total Fat $(\mathrm{g} / \mathrm{d})$} & Before & 85.2 & 6.1 & 76.6 & 3.5 & 101.0 & 9.8 & 62.4 & 4.0 & $<74.5$ \\
\hline & After & 71.8 & 3.6 & 84.5 & 5.0 & 66.8 & 2.9 & 56.9 & 5.5 & \\
\hline \multirow[t]{2}{*}{ Saturated Fat (g/d) } & Before & 37.7 & 2.9 & 33.3 & 1.8 & 40.3 & 6.3 & 23.8 & 2.0 & $<23.5$ \\
\hline & After & 25.9 & 1.6 & 35.8 & 2.5 & 25.5 & 1.4 & 22.6 & 2.9 & \\
\hline \multirow[t]{2}{*}{ Total Carbohydrate $(\mathrm{g} / \mathrm{d})$} & Before & 201.0 & 11.6 & 232.4 & 10.1 & 239.7 & 13.3 & 203.5 & 8.0 & $>260$ \\
\hline & After & 258.4 & 5.1 & 228.2 & 9.1 & 226.0 & 8.4 & 242.4 & 10.8 & \\
\hline \multirow[t]{2}{*}{ Non-milk extrinsic sugars $(\mathrm{g} / \mathrm{d})$} & Before & 52.4 & 3.3 & 74.6 & 5.0 & 64.4 & 6.2 & 62.1 & 4.2 & $<55.86$ \\
\hline & After & 56.9 & 2.2 & 73.4 & 4.1 & 53.0 & 2.3 & 65.2 & 3.1 & \\
\hline \multirow[t]{2}{*}{ Protein $(g / d)$} & Before & 68.9 & 4.4 & 67.2 & 4.2 & 72.9 & 4.4 & 55.7 & 4.0 & 50 \\
\hline & After & 85.4 & 1.7 & 68.7 & 3.2 & 63.4 & 1.5 & 73.1 & 6.7 & \\
\hline
\end{tabular}

Although positive changes were achieved in the macronutrient profile of menus served in the majority of the homes, the FSA guidelines were not fully met in any of the homes studied. More sustained intervention may be required to meet the guidelines in full.

This research was commissioned by the Food Standards Agency, project N14010. The views expressed are those of the authors.

1. Food Standard Agency (2007) Nutrient and food based guidelines for UK institutions. http://www.food.gov.uk/multimedia/pdfs/nutguideuk.pdf

2. McCance and Widdowson's The Composition of Foods integrated dataset, see www.food.gov.uk/science/dietarysurveys/dietsurveys/ 